Cambridge University Library

Home Using the Library $\quad$ Research $V$ Teaching \& Learning What's On $V$ Search \& find $V$ Collections $V$ About $V$ Giving $Y$ Contact

Cambridge University Library

Fragment of the Month: September 2013

collections

A medieval Karaite pedagogical grammar of Hebrew

Collections \& departments

By Nadia Vidro

Taylor-Schechter Genizah Research Unit

Fragment of the month

The Taylor-Schechter Collection contains many important literary and documentary fragments of Karatite origin. Yet how did these
fragments find their way into a collection that stems from the genizah of a Rabbanite synagogue? Two routes seem possible. Athough the history of Rabbanite - Karaite relations is not devoid of bitter polemics and conficts, in 10 th-12th-century Egypt the communities lived peacefully side by side, connected through intermarriage, political alllances and busness ties. Such close connech
Rabbanite and the Karaite communities may be one reason why we find Karaite fragments in the T-S Collection.

A second, completely different route, may have opened up in the 19 th century. A few decades before Solomon Schechter emptied and brought to Cambridge the contents of the Ben Erra Synagogue's genizat, a similar enterprise was undertaken by the most famous Karate
manuscript collector Abraham Firkovitch. In 1864 Firkovitch openend the genizizah chamber of the Dar Simna Synagogue, the main Karaite

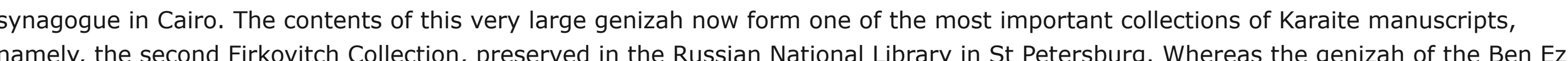
Synagogue was a repository for obsolete writings and contained mainly fragmentary material, the genizah of the Darr Simba Synagogue seems to have grown out of the synagogue's library as well as out of other older Karatite synagogal libraries inherited by the Dar Simha. Ezra Synagogoue's genizah felt that he 'liked it all' and moved its entire contents to Cambridge, Firkovitch careffully sorted the contents of the Där Simha genizah, choosing what he believed to be the most complete and valuable manuschpts. The rest of the manuscripts,
fragmentarily preserved, were sold to antigue dealers or to scholars and collectors who visited the Karaite genizah It it is, thes, Dot

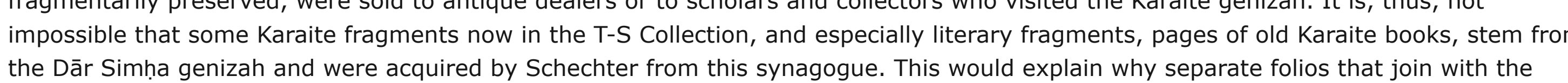
the Där Simha genizan and were acquired by Schechter from this synagogue. This would explain why separate folios that join with the
manuscripts in the Firkovitch Collection can be found in the T-S Collection and in other genizan collections worldwide.

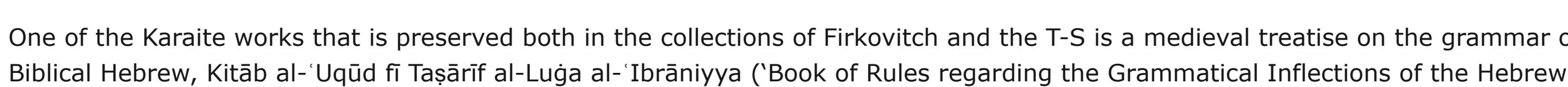
Language'). Kitäb al-'Uqüd was composed in Jerusalem in the middle of the 11 th century by an anonymous contemporary of the Karate grammatical luminary Abū al-Faraj Härūn ibn Faraj. This book is particularly interessting because it appears to be the first Karaite pedagoglcal grammar obscure for beginners' or 'I considered it necessary to mention this because I noticed that beginners mix up one with the other' seem to indicate mnemonics and a set of rules ('uāud) that link different verb forms to one another in order to facilitate the learning of verbal paradigms For example:

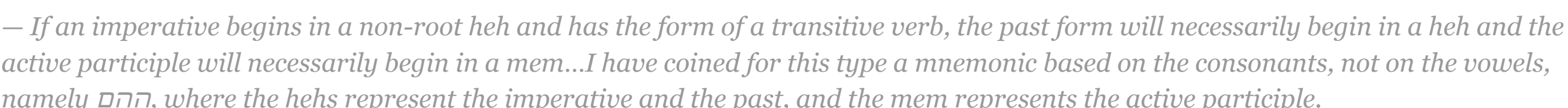
In modern terms, this rule describes the forms of hiph'il verbs, but medieval Karaites did not base their description of Hebrew verba In modern terms, this rule describes the forms of hiph'il verbs, but medieval Karaites did not base their description of Hebrew verba
morphology on the notion of binyanim, which was developed in the 10 th century by Rabbanite grammarians in ala for

Fragments of Kitäb al-Uaüd that are preserved in the T-S Collection originally belonged to two different codices.

1) T-SAr. 31.71 (2 folios) and T-S NS 301.64 (1 folio) belong to a copy of the treatise written in the Oriental (Egyptian) semi-cursive

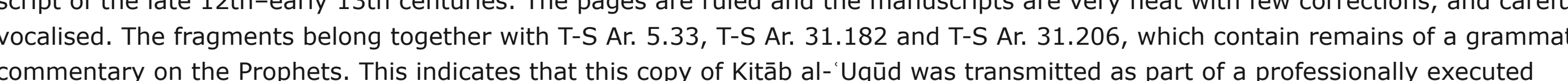
commentary on the Prophets. The 10
grammatical-exegetical anthologe

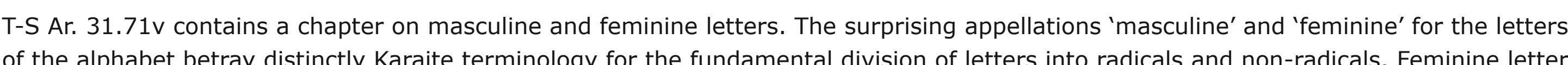

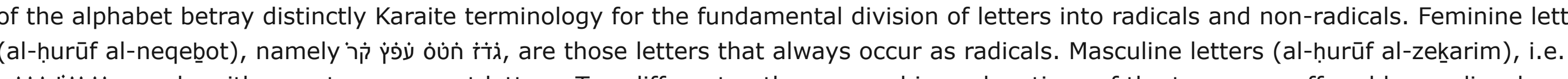

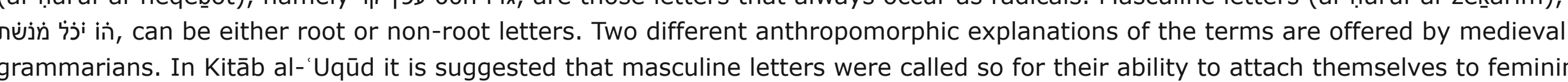
letters. This explanation refers to the situation when masculine letters function as affixes added to root letters. Another Karaite grammarian maintained that feminine letters are like women, who always stay at home, and masculine letters are like men, who are at
times at home and at times outside. This explanation reffects the fact that feminine letters are always radicals and masculine letters car times at home and at times outs
be either radicals or non-radicals

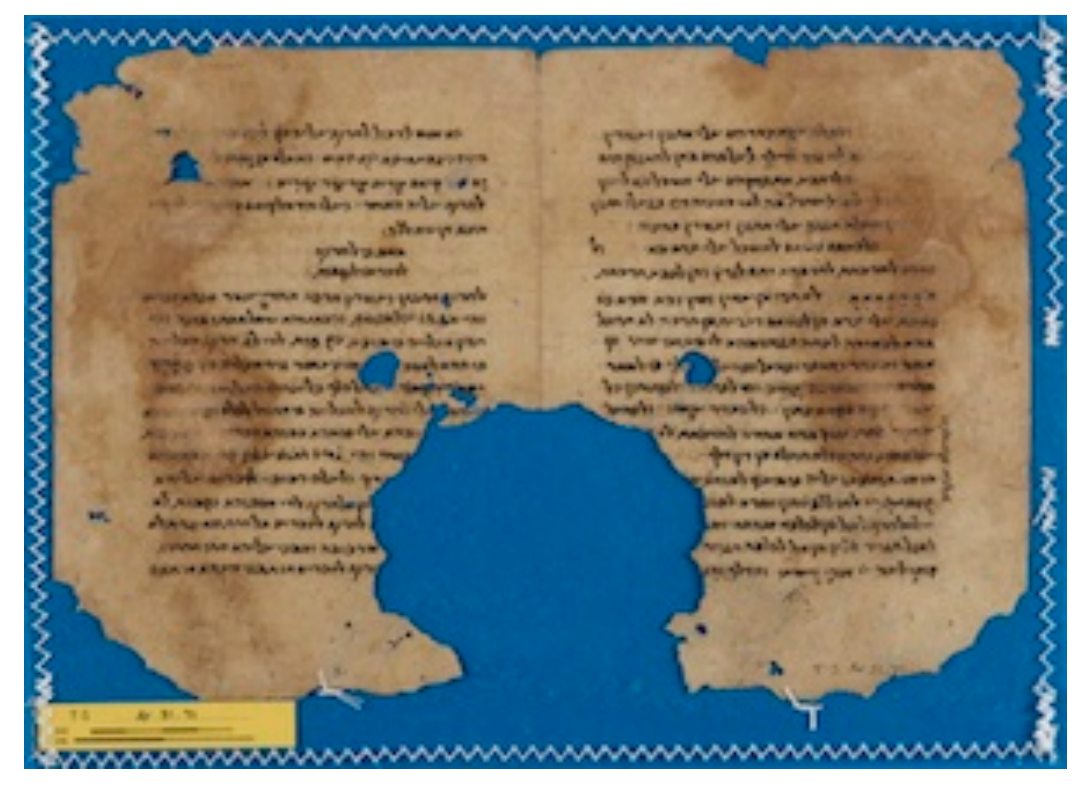

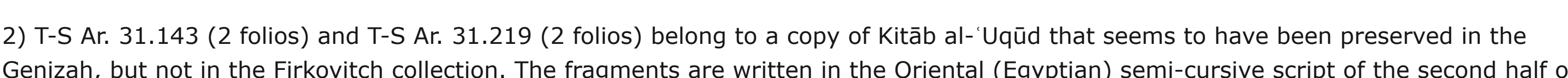
the 11 th-early 12 th century, suggesting that they were copied very soon after the book was written. The pages are not ruled and the
majority of the lines slant dounwwards or have a curve in the middle. The copy exhibits a relativively large pumber of cor deletions of incorrectly copied words or phrases that originated by homoeoteleuton, with the corrected version written as the next word the line right after the cancelled phrase, showing that corrections took place in the process of copying. This copy seems to have been T-S Ar. $31.143 r$ contains tables on verb forms with pronominal suffixes. This tabular layout is characteristic of Kkitab al- Uaud and
diststinguishes it from other known Karaite texts on Hebrew verbal morphology. In the tables all grammatically possible verb formcombinations are recorded and are provided either with an Arabic translation or with a corresponding form of the Arabic verb fá ala ("dix Sometimes two forms are inflected in parallel. Thus, in T-S Ar. 31.143r one finds a 4-column table on the feminine singular imperative ere

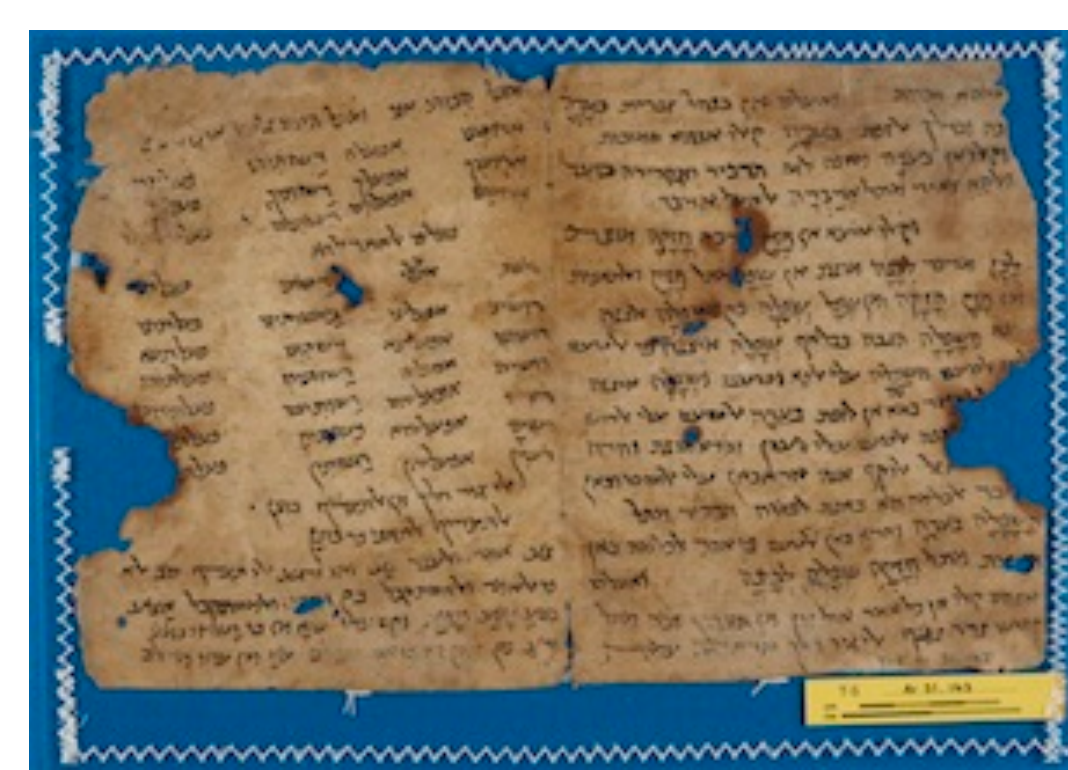

My analysis of grammatical theories and pedagogical strategies reflected in Kitäb al-'Uaüd has recently appeared in the Cambridge

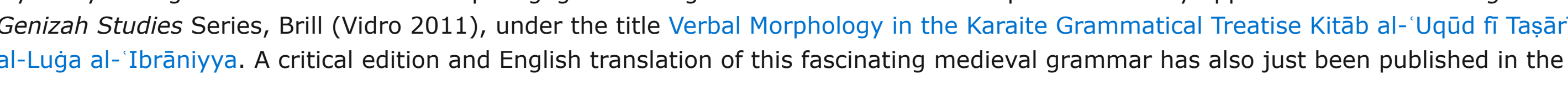
same series (Vidro 2013), under the titite A Medieval Karaite Pedagogical Grammar of Hebrew: a critical edition and English translation of

Bibliography

Ben-Shammai, H., 2010, 'Is "the Cairo Genizah" a proper name or a generic noun? On the relationship between the genizot of the Ben

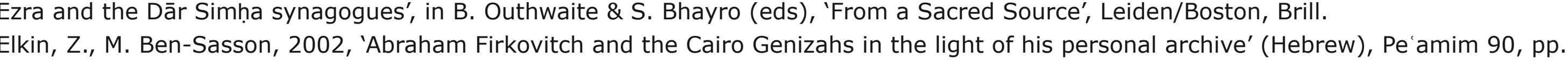

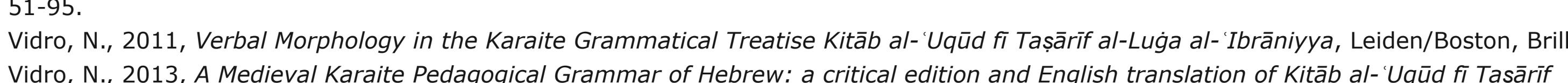

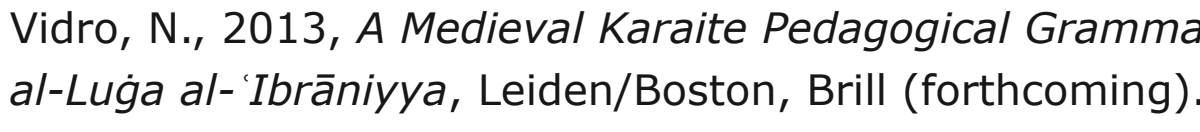

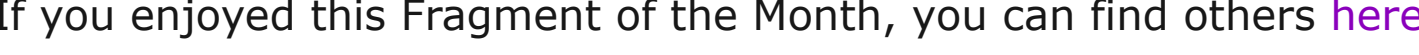

Contact us: genizah@lib.cam.ac.uk

The zoomable images are produced using Cloud Zoom, a jQuervimage zoom plugin
Cloud Zoom, Copyright (c) 2010, R Cecco, www.profosssorcloud.com

Licensed under the MIT License

Contact us Cambridge University Library, West Road,
Cambridge CB3 9DR, UK

Emaili: ibrarye@ilib.cam.ac.uk
Telix +4t4

Teli: $+44(0) 1223333000$
Fax: +44 (0) 1223333160

\section{Privacy Policy}

Privacy Policy

Diversifying Collections and Practices

Diversiffying Collections and Practices

\section{Social Media}

Library blogs

Instagram

Twitter

Facebook

YouTube

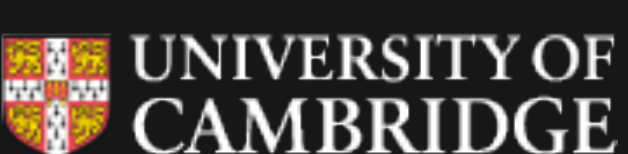

(9) 2020 University of Cambridge

University $A-Z$
Contact the University

Accessibility
Freedom of information
Terms and conditions
Study at Cambridge

Undergraduate
Postgraduate

Postgraduate
International students

Continuing education

Executive and professional ecucation

so

Research at Cambridge

How the University and Colleges work

Visiting the University

Map

Events

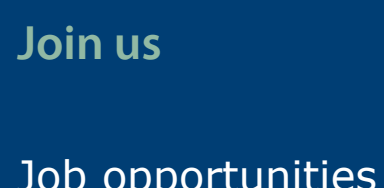

Job opportunities

News
Features

Discussion

Spotight on... 